\title{
Upaya Persuasi Calon Legislatif Etnis Tionghoa dalam Meraih Perhatian Generasi Milenial Etnis Tionghoa
}

\author{
Nadya Natasia Ria, Sinta Paramita \\ nadya.915150155@stu.untar.ac.id,sintap@fikom.untar.ac.id \\ Fakultas Ilmu Komunikasi Universitas Tarumanagara
}

\begin{abstract}
Ethnicity is one of the things that can influence millennial generation decisions. Opinion of millennial generation can be formed from persuasion communication carried out by Legislative Candidates. Efforts to persuade Chinese ethnic Legislative Candidates to reach the attention of the Chinese millennial generation are 3, namely propaganda, rhetoric and advertising. It aims to find out how the persuasion efforts of ethnic Chinese Legislative Candidates in grabbing the attention of the Chinese ethnic millennials. The theory used in this study is the theory of persuasion communication, political communication, communication perceptions and Chinese ethnicity. The method used in this study is a case study with a qualitative research approach. Data collection techniques used in the form of interviews, documentation and literature study with data analysis techniques namely data reduction, data presentation, and withdrawal and testing conclusions. The conclusion of this study is that persuasive efforts that are very influential for the millennial generation are propaganda. Ethics is not the main thing that can be a decision to choose for millennial generations.
\end{abstract}

Keywords: Persuasion Communication, Prospective Polehoa ethnic Legislation, Tianghoa ethnic Milenials generation

\begin{abstract}
Abstrak
Etnis adalah salah satu hal yang dapat mempengaruhi keputusan generasi milenial. Opini generasi milenial dapat terbentuk dari komunikasi persuasi yang dilakukan calon legislatif. Upaya persuasi calon legislatif etnis Tionghoa dalam meraih perhatian generasi milenial etnis Tionghoa ada tiga, yaitu propaganda, retorika dan iklan. Hal tersebut bertujuan untuk mengetahui bagaimana upaya persuasi calon legislatif etnis Tionghoa dalam meraih perhatian generasi milenial etnis Tionghoa. Teori yang digunakan dalam penelitian ini adalah teori komunikasi persuasi, komunikasi politik, persepsi komunikasi dan etnis Tionghoa. Metode yang digunakan dalam penelitian ini yaitu studi kasus dengan pendekatan penelitian secara kualitatif. Teknik pengumpulan data yang digunakan berupa wawancara, dokumentasi dan studi kepustakaan dengan teknik analisis data yaitu reduksi data, penyajian data, dan penarikan serta pengujian kesimpulan. Kesimpulan dari penelitian ini adalah upaya persuasi yang sangat berpengaruh bagi generasi milenial adalah propaganda. Etnis bukanlah hal utama yang mampu menjadi keputusan memilih bagi generasi milenial.
\end{abstract}

Kata Kunci : Komunikasi Persuasi, Calon Legislasi etnis tianghoa, Generasi Milenials etnis Tionghoa 


\section{Pendahuluan}

Komunikasi adalah cara manusia berinteraksi anatara satu dengan yang lainnya. Komunikasi adalah pembicaraan yang dilakukan dua arah, komunikan dan komunikator. Komunikasi ialah proses sosial yang dilakukan antar individu yang memakai simbol-simbol yang dapat menciptakan makna dalam lingkungan mereka (West dan Turner 2008). Komunikasi juga bukan hanya tentang berbicara tatap muka, melainkan penyampaian pesan melalui media elektronik ataupun media online. Hal tersebut dikarenakan terjalin interaksi antara komunikator (media) dan komunikan (khalayak) sehingga dapat disebut komunikasi. Komunikator adalah pihak yang mengirimkan sebuah pesan, dan komunikan adalah penerima pesan. Namun kerap kali komunikasi tidak tatap muka membuat presepsi orang menjadi berbeda-beda, hal ini akan membuat opini setiap individu berbeda.

Opini khalayak dapat terbentuk melalui apa yang ia lihat dan rasakan baik dari faktor internal maupun eksternal. Banyak komunikasi persuasi yang mampu membuat dan menggiring opini masyarakat. Komunikasi persuasi adalah proses penyampaian suatu pesan yang di lakukan oleh seseorang terhadap orang lain agar berubah sikap, opini dan tingkah lakunya melalui kesadarannya sendiri.

Komunikasi persuasif menurut Daanimo ada tiga yaitu propaganda, retorika dan iklan. Propaganda ialah suatu rangkaian pesan yang memiliki tujuan untuk mempengaruhi pendapat dan juga kelakuan khalayak, masyarakat atau sekelompok orang. Propaganda semata merujuk kepada kontrol opini dengan simbol penting, atau berkomunikasi secara lebih konkret. Propaganda menggunakan komunikasi lepas dalam menyebarkan harapan-harapan tertentu. Tujuannya adalah agar dapat mengubah cara bertindaknya masyarakat dan membiarkan masyarakat dapat meyakini bahwa tidak ada paksaan terhadap tindakan diri mereka sendiri (Baran dan Davis, 2010).

Retorika adalah sebuah teknik pembujukan secara persuasi untuk menghasilkan bujukan dengan melalui karakter pembicara, argumen $(\log 0)$ dan emosional. Iklan ialah komunikasi yang bertujuan untuk menggiring opini khalayak tentang suatu produk ataupun merk agar tanggapan dari khalayak mampu mengikuti tujuan dari pembuat iklan tersebut.

Ketiga teknik persuasi di atas adalah teknik-teknik yang digunakan oleh Calon Legislatif terhadap khalayak khususnya generasi milenial. Dalam hal persuasi ini, etnis bukan lah hal yang membuat generasi milenial memutuskan pilihannya, melainkan generasi milenial tetap melihat seperti apa kinerja dan latar belakang dari masing-masing calon legislatif tersebut. Etnis adalah pilihan terakhir untuk generasi milenial dapat menentukan pilihannya.

Berdasarkan latar belakang yang telah dipaparkan, maka perumusan masalah peneliti adalah sebagai berikut "Bagaimana Upaya Persuasi Calon Legislatif Etnis Tionghoa Dalam Meraih Perhatian Generasi Milenial Etnis Tionghoa"

\section{Metode Penelitian}

Pendekatan yang digunakan dalam penelitian ini adalah penelitian kualitatif. Penulisan ini dibuat oleh penulis untuk mengetahui bagaimana upaya persuasi calon legislatif etnis Tionghoa terhadap generasi milenial etnis Tionghoa. Penelitian kualitatif ialah keterkaitan terhadap studi hubungan sosial yang memiliki hubungan dengan fakta dari pluralisasi dunia kehidupan (Gunawan, 2014). 
Dalam penelitian ini, penulis menggunakan studi kasus sebagai metode penelitian. Penelitian studi kasus ialah suatu penelitian yang digunakan terhadap suatu objek yang disebut kasus, yang dilakukan secara seutuhnya, menyeluruh dan mendalam dengan menggunakan berbagai macam sumber data (Gunawan, 2014). Peneliti memilih metode studi kasus dikarenakan ada suatu fenomena atau kasus yang terjadi terhadap Pemilihan Umum Calon Legislatif 2019, di mana etnis dan identitas politik seorang calon legislatif mampu mempengaruhi calon pemilih.

Pemilihan umum yang dilakukan serentak pada tahun 2019 mampu membuat calon pemilih bingung terhadap pilihannya, terutama pada pemilihan calon legislatif. Latar belakang dan identitas diri pemilih maupun calon legislatif turut berperan. Studi kasus memungkinkan penulis untuk mempertahankan karakter berpikir secara keseluruhan dengan mempertimbangkan setiap asspek yang mempengaruhi tingkah laku sebagai sesuatu kesatuan yang utuh.

Dalam penelitian ini, penulis menggunakan beberapa teknik pengumpulan data diantaranya: wawancara, dokumentasi dan studi kepustakaan. Subjek penelitian adalah subjek yang mampu memahami informasi suatu objek penelitian sebagai pelaku maupun orang lain yang memahami objek penelitian (Bungin, 2011). Subjek yang akan diteliti dalam penelitian ini adalah calon legislatif etnis Tionghoa. Objek yang dipilih dalam penelitian ini adalah generasi milenial.

Teknik analisis data yang digunakan dalam penelitian ini adalah reduksi data, penyajian data, dan penarikan serta pengujian kesimpulan.

Dalam penelitian ini, penulis menggunakan teknik keabsahan data yaitu teknik triangulasi. Triangulasi adalah pengecekan data dari berbagai sumber, cara dan waktu. Dalam penelitian ini penulis menggunakan triangulasi sumber.triangulasi sumber ialah mencari kebenaran informasi tertentu secara mendalam melalui sumber-sumber memperoleh data. Triangulasi sumber berarti mencek ulang atau membandingkan informasi yang telah diperoleh melalui sumber-sumber berbeda (Gunawan, 2014).

\section{Hasil Temuan dan Diskusi}

Komunikasi persuasi adalah salah satu komunikasi yang dibutuhkan dan digunakan oleh calon legislatif agar mampu menciptakan dan menggiring opini masyarakat mengikuti sesuai harapan yang diinginkan. Dalam penelitian ini, penulis melakukan wawancara terhadap tiga calon legislatif Partai Solidaritas Indonesia, ketiga caleg tersebut melakukan tiga teknik dalam mempersuasi khalayak khususnya generasi milenial. Tiga teknik diantaranya ialah propaganda, retorika, dan iklan.

Persuasi politik propaganda yang dilakukan oleh calon legislatif etnis Tionghoa

Partai Solidaritas Indonesia terhadap generasi milenial dalam penelitian ini diantaranya:

a. Memasang spanduk, baliho dan poster di setiap daerah pilihnya masingmasing. Agar mampu membuat masyarakat yang melihatnya memiliki pemikiran yang di dinginkan oleh masing-masing calon legislatif.

b. Media sosial Instagram adalah media sosial yang juga berpengaruh bagi generasi milenial. Instagram ialah jejaring sosial berbasis fotografi yang hadir pada tahun 2010. Instagram mampu menggiring opini setiap generasi milenial dalam memutuskan pilihan.

Dalam penelitian ini para calon legislatif menyampaikan pesan melalui poster, spanduk dan baliho kepada masyarakat daerah pemilihannya masing-masing. Dalam 
penelitian ini, propaganda sangat sering digunakan oleh calon legislatif untuk menggiring opini khalayak terhadap tujuan yang diinginkan. Propaganda juga dapat dipakai untuk memperkenalkan calon legislatif dalam memperkenalkan dirinya dengan tujuan yang diinginkan.

Retorika adalah teknik pembujukan persuasi agar mampu menghasilkan bujukan dengan melalui karakter pembicara, argumen (logo) dan emosional. Dalam hal ini, ketiga calon legislatif yang penulis wawancarai memakai teknik retorika ini untuk mengambil perhatian dan suara khalayak. Ketiga calon legislatif tersebut melakukan pidato terhadap masyarakat masing-masing daerah pemilihannya, dan juga melakukan blusukan untuk menyuarakan visi-misi masing-masing calon legislatif.

Iklan ialah komunikasi yang bertujuan untuk menggiring opini khalayak tentang suatu produk ataupun merek agar tanggapan dari khalayak mampu mengikuti tujuan dari pembuat iklan tersebut. Dalam penelitian ini, persuasi tipe ini tidak terlalu banyak digunakan oleh para calon legislatif. Iklan kurang menjadi sarana bagi calon legislatif memperkenalkan dirinya dan menyuarakan visi-misinya. Para calon legislatif lebih memilih mengunggah di media sosial pribadi daripada memasang iklan.

Dari ketiga teknik di atas, propaganda adalah hal yang paling mampu mempersuasi khalayak khususnya generasi milenial agar mampu memiliki opini seperti yang calon legislatif inginkan. Propaganda di media sosial adalah propaganda yang mampu menjangkau generasi milenial karena generasi ini sangat erat kaitannya dengan internet dan media sosial.

Dalam hal ini, etnis bukanlah alasan utama generasi milenial memutuskan hak pilihnya. Generasi milenial tetap melihat seperti apa kinerja dan latar belakang dari masing-masing calon legislatif. Etnis adalah pilihan terakhir generasi milenial dalam memutuskan pilihannya.

\section{Simpulan}

Berdasarkan hasil penelitian yang penulis lakukan, disimpulkan bahwa upaya persuasi yang dilakukan oleh calon legislatif etnis Tionghoa dalam Pemilihan Umum 2019 terhadap generasi milenial etnis Tionghoa adalah dengan teknik propaganda, retorika dan iklan. Ketiga teknik tersebut mampu mempersuasi calon pemilih. Namun tujuan dari calon legislatif ialah masyarakat luas, tidak hanya tertuju kepada generasi milenial. Propaganda adalah upaya persuasi yang paling menguntungkan calon legislatif untuk mendapatkan suara.

Metode pendekatan terhadap generasi milenial yang digunakan ialah melalui media sosial dan internet. Media sosial dan internet ialah sarana paling tepat untuk digunakan calon legislatif untuk mendapatkan perhatian dari generasi milenial. Pasalnya, generasi milenial adalah generasi yang erat kaitannya dengan media sosial. Generasi milenial lebih dapat dijangkau dan dipersuasi melalui media sosial dan internet. Generasi ini sangat dekat dengan internet dan media sosial. Namun ada pula yang mampu terpersuasi dengan spanduk-spanduk yang terpasang di masing-masing daerah pemilihan calon legislatif.

Etnis adalah salah satu hal yang dapat menjadi keputusan memilih dari calon pemilih khususnya generasi milenial. Namun, etnis adalah pilihan terakhir untuk generasi milenial memutuskan pilihannya. Keputusan memilih generasi milenial tetap berdasarkan kinerja dari calon legislatif itu sendiri. 
Nadya Natasia Ria, Sinta Paramita: Upaya Persuasi Calon Legislatif Etnis Tionghoa dalam Meraih Perhatian Generasi Milenial Etnis Tionghoa

\section{Ucapan Terima kasih}

Dalam laporan ini penulis berterimakasih kepada dosen pembimbing dan juga semua narasumber yang telah berkenan melakukan wawancara dalam penelitian ini.

\section{Daftar Pustaka}

Bungin, B. (2010). Penelitian Kualitatif: Komunikasi, Ekonomi, Kebijakan Publik, dan Ilmu Sosial Lainnya. Jakarta: Kencana.

Baran, J. Stanley dan Davis, K. Dennis, 2010. Teori Komunikasi Massa: Dasar, Pergolakan, Dan Masa Depan. Jakarta: Salemba Humanika

Budiman, J \& Tamburian, D. 2018. Komunikasi Politik Megawati Dalam Membangun Brand Image Partai. Ejournal Fakultas Ilmu Komunikasi Universitas Tarumanagara, Vol 2 No.2

Nimmo, D. (2011). Political Communication and Public Opinion in America (7th ed.). Bandung: Goodyear Publishing Co.

Gunawan, Imam. 2014 Metode Penelitian Kualitatif: Teori dan Praktik. Jakarta : Bumi Aksara.

Kartikantri. D. A, Priyatna. C. C. Dan Hafiar. H. 2015. Perbedaan Sikap Pemilih Pemula Antara Peserta Dan Bukan Peserta "Roadshow Pendidikan Pemilu". Ejournal Fakultas Ilmu Komunikasi Universitas Tarumanagara, Vol 7 No.1

Mukarom. Z. (2016). Komunikasi Politik. Jakarta. CV Pustaka Setia.

Vivian. C \& Candraningrum. D. A. 2018. E-Wom Kalangan Milenial Terhadap Akun @makansampaikenyang Sebagai Pemberi Rekomendasi Kuliner. Ejournal Fakultas Ilmu Komunikasi Universitas Tarumanagara, Vol 2 No.2

West, R., \& Turner, L. H. (2008). Pengantar Teori Komunikasi Analisis dan Aplikasi. Jakarta: Salemba Humanika. 